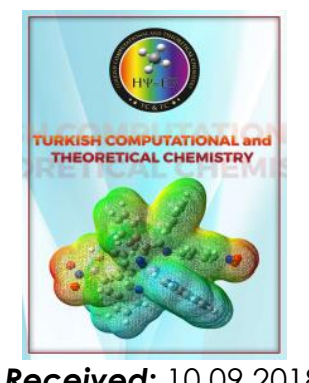

Turkish Computational and Theoretical Chemistry

Turkish Comp Theo Chem (TC\&TC)

Volume(Issue): 3(1) - Year: 2019 - Pages: 17-24

e-ISSN: $2602-3237$

https://doi.org/10.33435/tcandtc. 458615

Accepted: 30.01 .2019

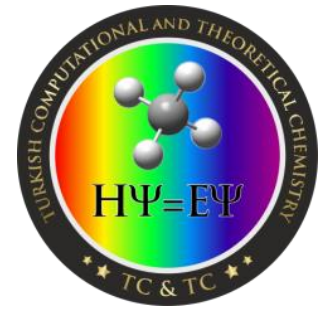

Research Article

\title{
Molecular docking study for evaluating the binding mode and interaction of 2, 4- disubstituted quiloline and its derivatives as potent anti-tubercular agents against Lipoate protein B (LipB)
}

\author{
Shola Elijah ADENIJI ${ }^{l}$, Sani UBA, Adamu UZAIRU \\ Department of Chemistry, Ahmadu Bello University, Zaria-Nigeria
}

\begin{abstract}
: 2, 4-disubstituted quilonine derivatives which have been reported as potent anti-tubercular agents. Thus, Mycobacterium tuberculosis receptor (LipB) was selected as a potential drug target and docked with these derivatives. The molecular docking evaluation showed that the binding affinities of all the derivatives range from (- 3.2 and $-18.5 \mathrm{kcal} / \mathrm{mol}$ ). Two compounds (ligand 8 and ligand 17) of the derivatives were found to have the most promising binding affinity values $(-15.4$ and $-18.5 \mathrm{kcal} / \mathrm{mol})$ which were observed to be greater than recommended drug isoniazid $(-14.6 \mathrm{kcal} / \mathrm{mol})$. The findings of this research could be helpful for the design of new and more potent anti-tubercular analogs.
\end{abstract}

Keywords: Tuberculosis, Binding affinity, Molecular docking, LipB, Quiloline

\section{Introduction}

Tuberculosis (TB) is among the common infectious diseases caused by bacteria which causes of death worldwide claiming many lives annually. According to an estimation, one third of the world's population is infected with Mycobacterium tuberculosis and nearly 9 million people have been exposed to this disease caused by M. tuberculosis each year [1]. Recommended drug like rifampicin, ciprofloxacin, ethambutol and isoniazid are available for curing tuberculosis. However emergence of multidrug resistant (MDR) and extensively drug resistant (XDR) tuberculosis resist current drugs and this give a big challenge towards successful treatment of tuberculosis [2]. This led to development of new therapeutics against diverse strains of M. tuberculosis [3]. New synthetized 2, 4-disubstituted quilonine derivatives have been reported to demonstrates tuberculosis inhibition activity [4]. It is very important to know which receptor in the tubercle bacillus is a good drug target when developing and designing of novel antitubercular drugs. There are many enzymes that partake in metabolic process like the growth of the bacterium and one among them is Lipoate biosynthesis protein $\mathrm{B}$ (LipB).

LipB is an enzyme that participates in lipoylation; it catalyzes the transfer of endogenous octanoic acid to lipoyl domains by forming thioester bond to the 4- phosphopanthetheine cofactor of the acyl carrier protein (ACP). Lipoyl synthase (Lip A) then converts octanoyl derivatives into lipoyl derivatives. Thus it acts as the essential protein involved in activating the bacterium's metabolic activities [5].

The advancement of computational chemistry led to new challenges of drug discovery [6]. Molecular docking is a computational approach which have been widely applied to pharmacology hypothesis and testing. It serves as a tool in drug discovery field to examine and elucidate the binding orientation of molecule (ligand) to receptor

\footnotetext{
${ }^{1}$ Corresponding Author

e-mail: shola4343@gmail.com
} 
Turkish Comp Theo Chem (TC\&TC), 3(1), (2019), 17 - 24

Shola Elijah ADENIJI, Sani UBA, Adamu UZAIRU

target site [7]. This technique saves resources, time and accelerate the process of developing novel compounds against multi-resistance diseases [8].

Molecular modeling investigations were carried out with the aim of understanding the binding mode and interactions of 2, 4-disubstituted quilonine derivatives into the active site of LipB receptor.

\section{Materials and Method}

\subsection{Optimization}

The chemical structures of the molecules were drawn with Chemdraw ultra Version 12.0. [9]. Each molecule was first pre-optimized with the molecular mechanics (MMFF) and further reoptimize with Density functional theory (DFT) utilizing the B3LYP and $6-31 G^{*}$ basis set $[10,11]$. The Spartan files of all the optimized molecules were then saved in PDB file format, which is the recommended input format in Ligplot version 1.4.5 and Discovery Studio Visualizer software.

\subsection{Docking Procedure}

The molecular docking studies were carried out between 2, 4-disubstituted quiloline derivatives and M. tuberculosis target site (LipB). The molecular structures 2, 4-disubstituted quiloline derivatives were presented Table 1. These compounds together with their biological activities were obtained from the literature [4]. While the crystal structure of $M$. tuberculosis receptor (LipB) was obtained from the Protein Data Bank with code 1W66. All bound substances (ligands and cofactors) and solvent molecules associated with the receptor were removed. The prepared receptor and ligand were shown in Figure 1. The prepared ligands were docked into the binding site of the prepared structure of LipB using Autodock Vina incorporated in Pyrx software. The docking results were then visualized and analyzed using Ligplot version 1.4.5 and Discovery Studio Visualizer software.

Table 1. Molecular structure of 2, 4-disubstituted quiloline derivatives and their activities

(Oc)


Turkish Comp Theo Chem (TC\&TC), 3(1), (2019), 17 - 24

Shola Elijah ADENIJI, Sani UBA, Adamu UZAIRU

Table 1 is continued

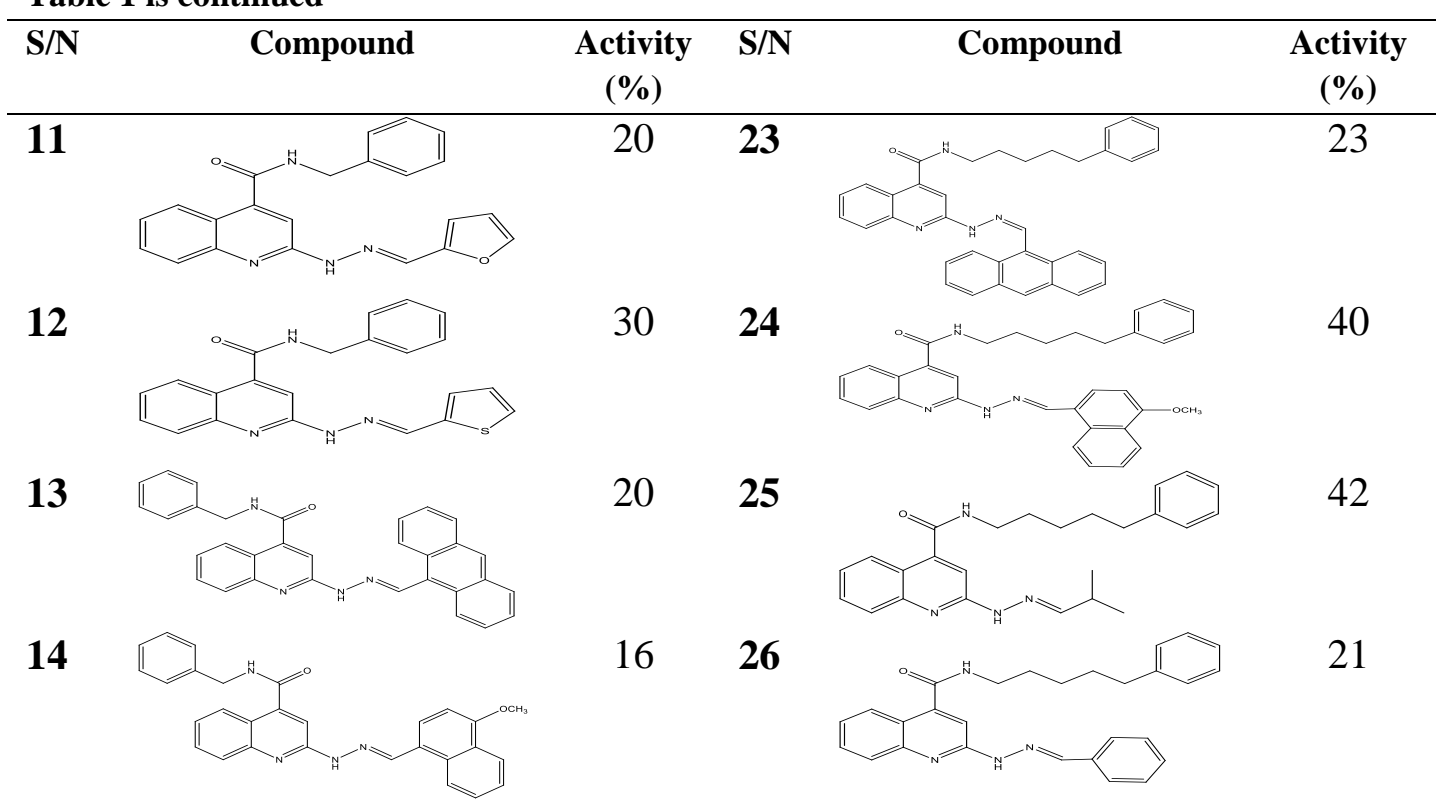

15

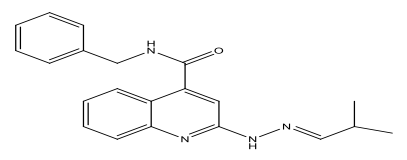

16

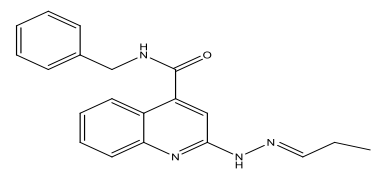

17

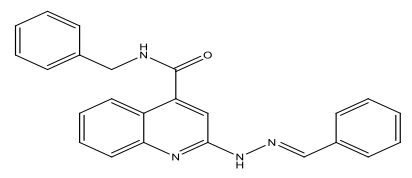

18

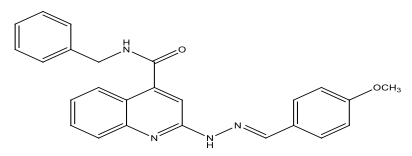

19

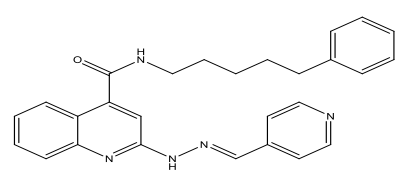

20

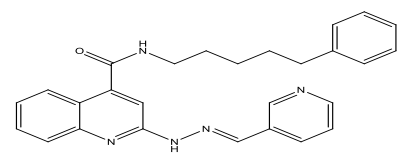

21

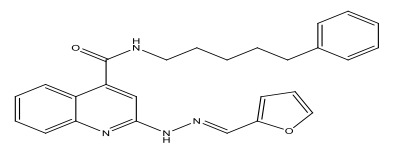

22

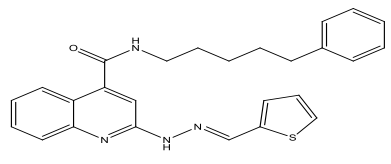

42

27

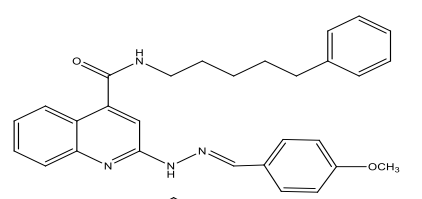

27

28

99

29

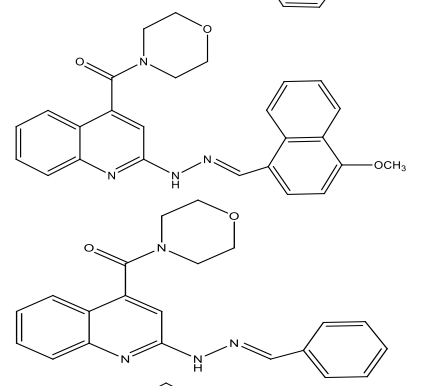

21

30

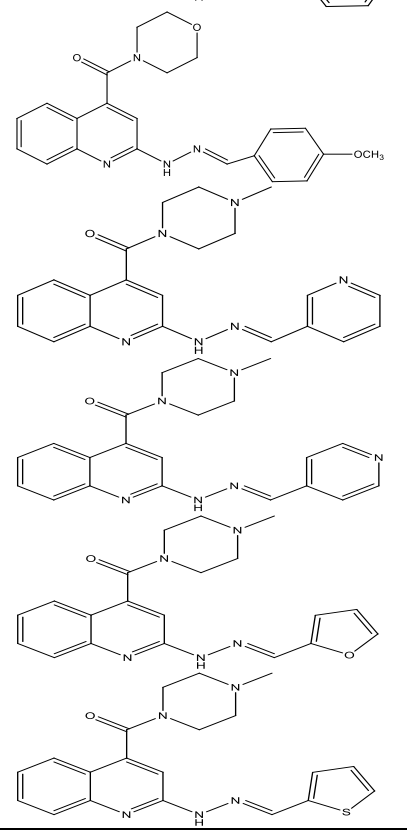

30

31

10

32

40

7

3

10

1

28

21

10

19 
Turkish Comp Theo Chem (TC\&TC), 3(1), (2019), 17 - 24

Shola Elijah ADENIJI, Sani UBA, Adamu UZAIRU

Table 1 is continued

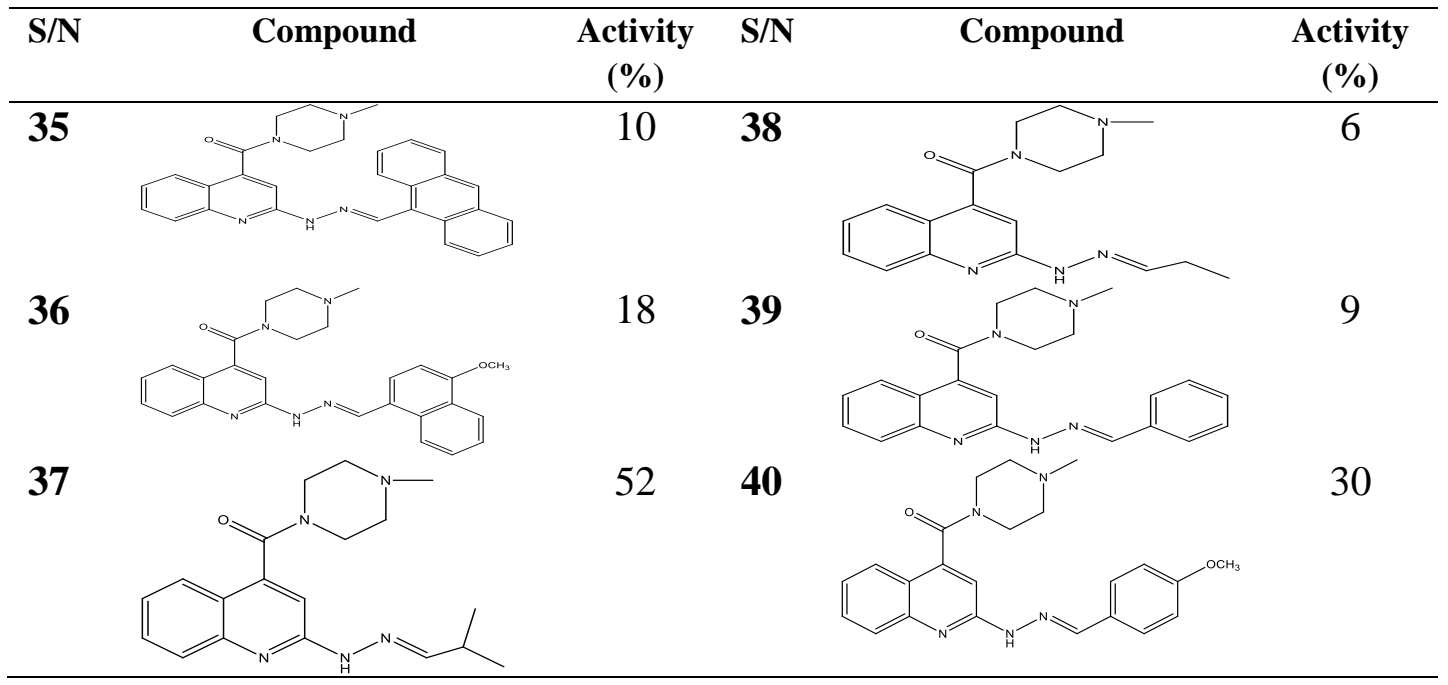

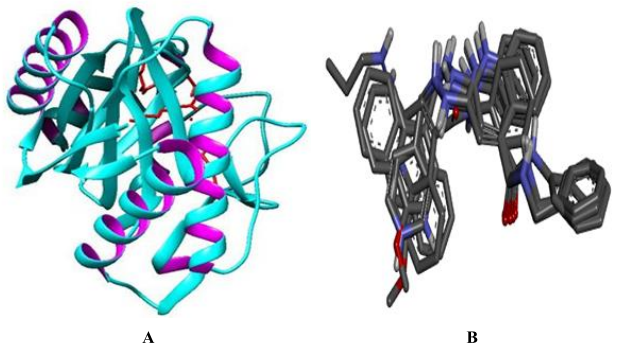

Figure 1. (A) Prepared structure of LipB, (B) 3D structures of the prepared ligands.

\section{Results and discussion}

Molecular docking studies were carried out in order to elucidate the interactions and the binding modes between the target (LipB) and 2, 4disubstituted quiloline derivatives as potent antimycobacterium tuberculosis. The docking results clearly show that the binding affinities of these ligands correlate with their activity values. The binding energy values for all the compounds range from (- 3.2 and $-18.5 \mathrm{kcal} / \mathrm{mol}$ ) as reported in Table 2. Compound 8 and 17 have higher binding energy values from $(-15.4$ and $-18.5 \mathrm{kcal} / \mathrm{mol})$ which were greater than the binding affinity of recommended drugs; isoniazid $(-14.6 \mathrm{kcal} / \mathrm{mol})$. Compound 8 and 17) with best binding affinities were visualized and analyzed using Ligplot version 1.4.5 and Discovery Studio Visualizer. The 3D and 2D interactions of ligand 8 and 17 as well as recommended antitubercular drugs (isoniazid) with binding site of LipB were shown in Figure 2 and Figure 3.

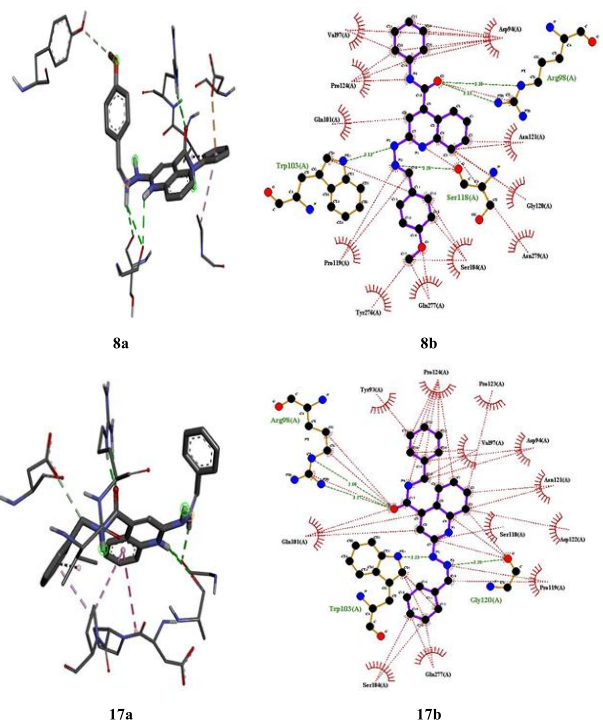

Figure 2. (8a) and (8b) show the $3 \mathrm{D}$ and $2 \mathrm{D}$ interactions between LipB and Ligand 16. (17a) and (34b) show the 3D and 2D interactions between LipB and Ligand 34.

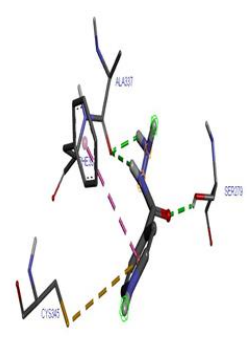

$I_{A}$

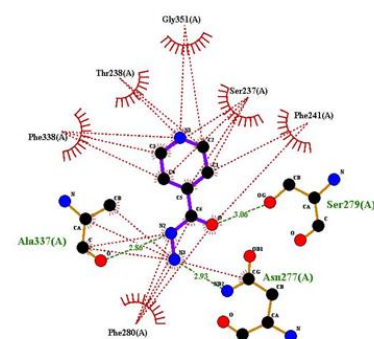

$\mathrm{I}_{\mathrm{B}}$
Figure 3. $\left(\mathrm{I}_{\mathrm{A}}\right)$ and $\left(\mathrm{I}_{\mathrm{B}}\right)$ show the $3 \mathrm{D}$ and $2 \mathrm{D}$ interactions between LipB and Isoniazid. 
Turkish Comp Theo Chem (TC\&TC), 3(1), (2019), 17 - 24

Shola Elijah ADENIJI, Sani UBA, Adamu UZAIRU

Table 2. Binding energy, hydrogen bond and hydrophobic interaction of the ligands with M. tuberculosis target (LipB)

\begin{tabular}{|c|c|c|c|c|}
\hline \multirow[t]{2}{*}{ Ligand } & \multirow{2}{*}{$\begin{array}{c}\text { Binding } \\
\text { Energy } \\
\text { (BA) } \\
\text { Kcal/mol }\end{array}$} & \multicolumn{2}{|c|}{ Hydrogen bond } & \multirow{2}{*}{$\begin{array}{l}\text { Hydrophobic interaction } \\
\text { Amino acid }\end{array}$} \\
\hline & & $\begin{array}{l}\text { Amino } \\
\text { acid }\end{array}$ & $\begin{array}{l}\text { Bond length } \\
\qquad\left(\mathrm{A}^{\circ}\right)\end{array}$ & \\
\hline 1 & -6.5 & PRO124 & 2.2054 & HIS220, TRP103, GLN277, VAL278 \\
\hline 2 & -5.7 & ARG98 & 2.1875 & VAL68, ARG98, ASP94, TRP103 \\
\hline 3 & -5.4 & ARG98 & 2.8943 & PRO285, GLN277, HIS220, VAL78 \\
\hline 4 & -7.8 & $\begin{array}{c}\text { ASP94 } \\
\text { TRP182 }\end{array}$ & $\begin{array}{l}2.3422 \\
1.4543\end{array}$ & GLN101, VAL138, CYS112, PRO124 \\
\hline 5 & -5.8 & ARG98 & 2.1345 & VAL97, PRO124, HIS220 \\
\hline 6 & -6.1 & ASP94 & 2.4834 & GLN101, PRO119, ASP122, VAL278 \\
\hline 7 & -5.8 & SER102 & 2.4653 & TRP182, ALA167, SER247, ASP122 \\
\hline 8 & -15.4 & $\begin{array}{l}\text { ARG98 } \\
\text { ARG98 } \\
\text { TRP103 } \\
\text { SER118 }\end{array}$ & $\begin{array}{l}3.1319 \\
3.1271 \\
3.1252 \\
3.2014\end{array}$ & $\begin{array}{c}\text { VAL97, ASP94, PRO124, GLN101, ASN121, } \\
\text { GLY120, ASN279, SER104, GLN277, } \\
\text { TYR276, PRO119 }\end{array}$ \\
\hline 9 & -6.3 & HIS220 & 2.4765 & $\begin{array}{c}\text { PRO119, ALA173 , TRP182, SER247, } \\
\text { PHE228 }\end{array}$ \\
\hline \multirow[t]{2}{*}{10} & -7.4 & LEU213 & 1.4234 & MET99, TRP182, SER118, PHE168, ASP122 \\
\hline & & ARG184 & 2.1362 & VAL78 \\
\hline \multirow[t]{2}{*}{11} & -8.7 & PRO119 & 1.3454 & ARG98, SER247, ASP94, VAL182, VAL77 \\
\hline & & GLY120 & 1.9854 & \\
\hline \multirow[t]{2}{*}{12} & -8.6 & ASP94 & 2.1834 & PRO285, GLY120, SER118, PHE168, \\
\hline & & TRP103 & 2.5645 & VAL78, GLY120 \\
\hline \multirow[t]{2}{*}{13} & -8.4 & SER104 & 2.4533 & CYS145, TRP162, ASP122, VAL78, ARG98, \\
\hline & & VAL77 & 1.6987 & PRO126 \\
\hline 14 & -6.8 & ARG98 & 1.99395 & ALA67, CYS174, ASN74, MET99, GLY120 \\
\hline \multirow[t]{3}{*}{15} & -10.3 & VAL169 & 1.4351 & ASP122, MET99, PHE232, VAL98, \\
\hline & & ARG134 & 2.4543 & \\
\hline & & $\mathrm{PRO} 285$ & 1.5443 & \\
\hline \multirow[t]{2}{*}{16} & -8.1 & GLY145 & 1.6328 & SER118, ALA223, MET145, LEU164, \\
\hline & & SER205 & 2.6751 & MET99, VAL98 \\
\hline \multirow[t]{4}{*}{17} & -18.5 & ARG98 & 2.8013 & TRY93, PRO124, VAL97, PRO123, ASP94, \\
\hline & & ARG98 & 3.2704 & ASN121, ASP122, PRO119, GLN277, \\
\hline & & TRP103 & 3.2287 & SER104, GLN101, SER118 \\
\hline & & GLY120 & 3.2821 & \\
\hline
\end{tabular}


Turkish Comp Theo Chem (TC\&TC), 3(1), (2019), 17 - 24

Shola Elijah ADENIJI, Sani UBA, Adamu UZAIRU

Table 2 is continued.

\begin{tabular}{|c|c|c|c|c|}
\hline \multirow[t]{2}{*}{ Ligand } & \multirow{2}{*}{$\begin{array}{c}\text { Binding } \\
\text { Energy } \\
\text { (BA) } \\
\text { Kcal/mol }\end{array}$} & \multicolumn{2}{|c|}{ Hydrogen bond } & \multirow{2}{*}{$\begin{array}{l}\text { Hydrophobic interaction } \\
\text { Amino acid }\end{array}$} \\
\hline & & $\begin{array}{l}\text { Amino } \\
\text { acid }\end{array}$ & $\begin{array}{l}\text { Bond length } \\
\qquad\left(\mathrm{A}^{\mathrm{o}}\right)\end{array}$ & \\
\hline 18 & -7.4 & PRO & 3.5624 & PHE177, PRO285, VAL27, MET99, PRO34 \\
\hline 19 & -8.5 & $\begin{array}{l}\text { LEU114 } \\
\text { ALA78 }\end{array}$ & $\begin{array}{l}2.3441 \\
1.3423\end{array}$ & $\begin{array}{c}\text { GLY232, VAL228, PHE168, TYR276, } \\
\text { LEU164, VAL228 }\end{array}$ \\
\hline 20 & -5.8 & $\begin{array}{l}\text { ALA167 } \\
\text { ARG94 }\end{array}$ & $\begin{array}{l}2.3433 \\
2.4551\end{array}$ & MET99, LYS136, VAL228, ALA233, \\
\hline 21 & -6.4 & MET99 & 1.7866 & PHE88, TRP142, PRO169, LEU 156, VAL78 \\
\hline 22 & -8.2 & $\begin{array}{l}\text { GLN223 } \\
\text { TYR276 }\end{array}$ & $\begin{array}{l}2.1123 \\
1.5442\end{array}$ & $\begin{array}{c}\text { LEU103, ARG98, ALA167, MET234, } \\
\text { PHE168 }\end{array}$ \\
\hline 23 & -8.8 & $\begin{array}{l}\text { PHE212 } \\
\text { TRP182 }\end{array}$ & $\begin{array}{l}2.3121 \\
1.2328\end{array}$ & LEU123, VAL78, SER119, TYR276, ALA233 \\
\hline 24 & -10.7 & $\begin{array}{l}\text { LSY146 } \\
\text { TRP143 }\end{array}$ & $\begin{array}{l}2.3432 \\
2.1349\end{array}$ & $\begin{array}{c}\text { CYS254, PHE168, TRP182, VAL78, } \\
\text { ALA167, VAL82 }\end{array}$ \\
\hline 25 & -10.9 & $\begin{array}{l}\text { ARG98 } \\
\text { CYS156 }\end{array}$ & $\begin{array}{l}2.1156 \\
1.7643\end{array}$ & LEU 103, ALA167, ARG386, TRP112 \\
\hline 26 & -8.5 & TRP182 & 2.8543 & ALA143, ARG72, GLN154, VAL78 \\
\hline 27 & -10.6 & $\begin{array}{l}\text { PHE256 } \\
\text { ARG143 }\end{array}$ & $\begin{array}{l}1.5332 \\
1.4322\end{array}$ & $\begin{array}{c}\text { CYS345, PHE 168, ALA176, GLN 322, } \\
\text { TRP182, }\end{array}$ \\
\hline 28 & -4.8 & ------------ & ------------- & MET 232, PRO285, ALA137, SER108 \\
\hline 29 & -4.2 & ------------ & ------------- & VAL178, PRO169, LEU164, VAL228, PHE98 \\
\hline 30 & -5.7 & ARG145 & 1.8754 & $\begin{array}{c}\text { VAL228, LEU234, CYS 144, VAL78, } \\
\text { ALA233 }\end{array}$ \\
\hline 31 & -3.2 & ------------ & ------------- & SER237,THR238, HIS220, PHE168, ALA167 \\
\hline 32 & -7.9 & $\begin{array}{l}\text { TRP182 } \\
\text { MET99 }\end{array}$ & $\begin{array}{l}2.3433 \\
1.3433\end{array}$ & $\begin{array}{c}\text { PRO94, PRO34, PHE93, VAL178, PRO169, } \\
\text { PHE241 }\end{array}$ \\
\hline 33 & -8.6 & $\begin{array}{l}\text { SER104 } \\
\text { TRP219 }\end{array}$ & $\begin{array}{l}2.5433 \\
2.1117\end{array}$ & $\begin{array}{l}\text { GLY232, VAL228, PHE168, TRP182, } \\
\text { LYS175 }\end{array}$ \\
\hline 34 & -5.8 & ARG98 & 3.0882 & ALA137, VAL122, TRP182, PHE220 \\
\hline 35 & -5.4 & TYR276 & 2.4544 & PHE168, HIS220, VAL78 \\
\hline 36 & -7.1 & GLN277 & 3.2433 & $\begin{array}{c}\text { ALA233 PHE338, TYR276, CYS345, } \\
\text { ASP122, }\end{array}$ \\
\hline 37 & -11.6 & $\begin{array}{l}\text { HIS220 } \\
\text { SER104 } \\
\text { MET99 }\end{array}$ & $\begin{array}{l}2.4544 \\
1.3444 \\
1.3344\end{array}$ & GLY120, SER118, PHE285, GLY120 \\
\hline 38 & -4.4 & ------------ & ------------- & $\begin{array}{c}\text { LEU207, VAL228, LEU73, HIS220, VAL78, } \\
\text { PRO245 }\end{array}$ \\
\hline 39 & -5.2 & TYR276 & 2.3647 & PHE168, TRP182, TRP182 TYR276, ALA167 \\
\hline
\end{tabular}


Turkish Comp Theo Chem (TC\&TC), 3(1), (2019), 17 - 24

Shola Elijah ADENIJI, Sani UBA, Adamu UZAIRU

Table 2 is continued.

\begin{tabular}{ccccc}
\hline Ligand & $\begin{array}{c}\text { Binding } \\
\text { Energy } \\
(\mathrm{BA}) \\
\text { Kcal/mol }\end{array}$ & Hydrogen bond & Hydrophobic interaction \\
& & Amino & Bond length \\
$\left(\mathrm{A}^{\mathrm{o}}\right)$ & Amino acid \\
\hline $\mathbf{4 0}$ & -8.4 & ALA167 & 2.2762 & ARG165, GLN385, TYR276, CYS234, \\
& & LEU137 & 2.2344 & VAL167, GLN385, ARG98, GLY215 \\
Isoniazid & -14.6 & SER279 & 3.0558 & GLY351, THR238, SER237, PHE241, \\
& & ALA337 & 2.8619 & PHE280, PHE338 \\
& & ASN277 & 2.9316 & \\
\hline
\end{tabular}

Ligand 8 formed four hydrogen bonds by ARG98, ARG98, TRP103 and SER118 with the length of $3.1319,3.1271,3.1252$ and $3.2014^{\circ} \mathrm{A}$ respectively. Hydrophobic interactions adhere the ligand to the binding site as shown in Figure 4 and 5. Ligand 8 formed hydrophobic interactions with VAL97, ASP94, PRO124, GLN101, ASN121, GLY120, ASN279, SER104, GLN277, TYR276 and PRO119. Ligand 17 formed four hydrogen bonds $\left(2.8013,3.2704,3.2287\right.$ and $\left.3.2821^{\circ} \mathrm{A}\right)$ with ARG98, ARG98, TRP103 and GLY120 of the target while hydrophobic interactions were observed TRY93, PRO124, VAL97, PRO123, ASP94, ASN121, ASP122, PRO119, GLN277, SER104, GLN101 and SER118. The recommended drugs; Isoniazid formed three hydrogen bonds (3.0558, 2.8619 and $\left.2.9316^{\circ} \mathrm{A}\right)$ with SER279, ALA337 and ASN277 while hydrophobic bonds were observed with GLY351, THR238, SER237, PHE241, PHE280 and PHE338. Increase in number of hydrogen bonds observed in ligand 8 and 17 accounts for their high binding affinities (- 15.4 and $-18.5 \mathrm{kcal} / \mathrm{mol}$ ) compared to the recommended drugs; Isoniazid ($14.6 \mathrm{kcal} / \mathrm{mol}$ ).

Ligand 8 formed a total of four hydrogen bonds with active site of LipB. The $\mathrm{C}=\mathrm{O}$ of the ligand acts as hydrogen acceptor and formed two hydrogen bonds with ARG98 of the target. The N-H group (hydrazine) of the ligand acts as hydrogen donor and formed two hydrogen bonds with SER118 and TRP103 of the target. Ligand 17 formed a total of five hydrogen bonds with binding site of LipB. The $\mathrm{C}=\mathrm{O}$ of the ligand also acts as hydrogen acceptor and formed two hydrogen bonds with ARG98 of the target. The N-H group (hydrazine) of the ligand acts as hydrogen donor and formed two hydrogen bonds with GLY 120 and TRP103 of the target. The hydrogen bond formation alongside with the hydrophobic interaction provide an evidence that ligand 8 and 17 are can be hit inhibitors for LipB receptor. Elucidations of hydrogen donor and hydrogen acceptor region were shown in Figure 6 and 7 .

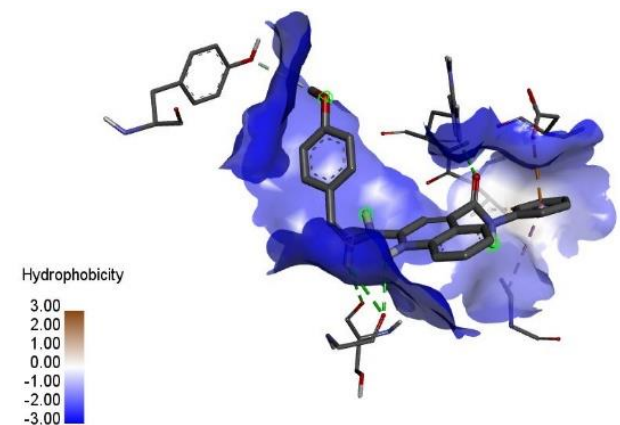

Figure 4. Hydrophobic interaction between the ligand 8 and M. tuberculosis target (LipB).

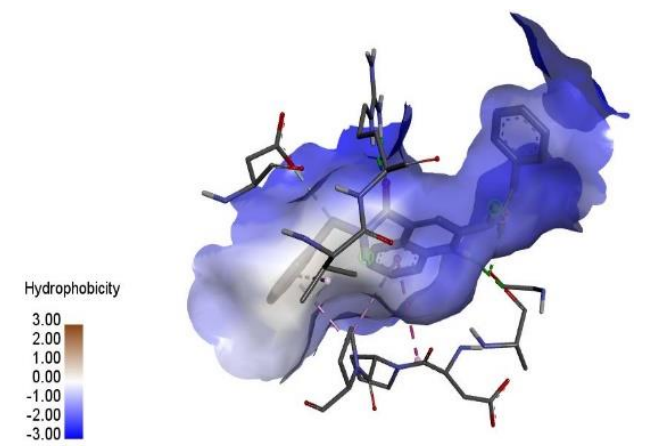

Figure 5. Hydrophobic interaction between the ligand 17 and M. tuberculosis target (LipB). 


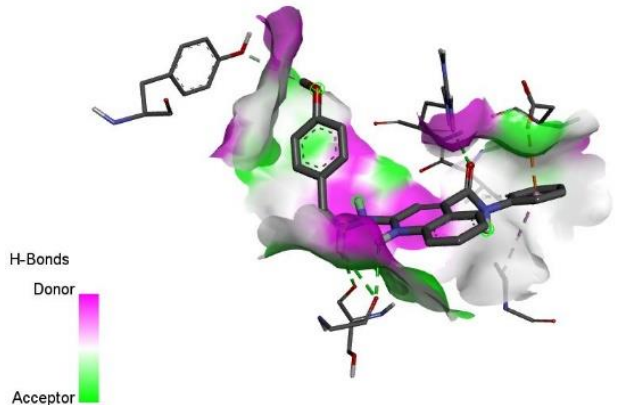

Figure 6. H-bond between the ligand 8 and $M$. tuberculosis target (LipB).

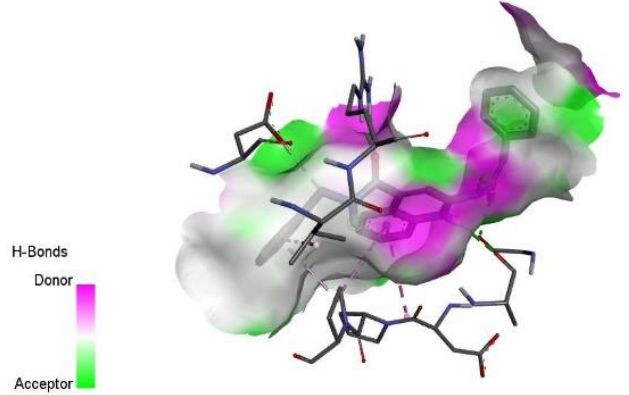

Figure 7. H-bond between the ligand 17 and $M$. tuberculosis target (LipB)

\section{Conclusion}

Molecular docking evaluation was carried out on series of 2, 4-disubstituted quilonine derivatives as potent inhibitor against Mycobacterium tuberculosis target (LipB). Two compounds (ligand 8 and ligand 17) were found to have the most promising binding energy values (-15.4 and -18.5 $\mathrm{kcal} / \mathrm{mol}$ ) which were to be greater than recommended drug isoniazid $(-14.6 \mathrm{kcal} / \mathrm{mol})$. It's concluded that compound 8 and 17 could serve as potent anti-tubercular hit molecules and can be improve by structure base design.

\section{References}

[1] C.A.Benson, J.T. Brooks, K.K. Holmes, J.E. Kaplan, H. Masur, A. Pau, Guidelines for prevention and treatment opportunistic infections in HIV-infected adults and adolescents; recommendations from CDC, the National Institutes of Health, and the HIV Medicine Association/Infectious Diseases Society of America 2009.

[2] G. Lamichhane, J.S. Freundlich, S. Ekins, N. Wickramaratne, S.T. Nolan, W.R. Bishai, Essential metabolites of Mycobacterium tuberculosis and their mimics. Mol Bio. 10 (1) (2011).

[3] D.O. Davies, Multi-Drug Resistant Tuberculosis. Dir Tuberc Res Unit, Cardiothorac Centre, Thomas Drive, Liverpool 1(999).

[4] A. Nayyar, R. Jain, Synthesis and antituberculosis activity of 2, 4-disubstituted quinolines. Indian journal of chemistry 47 : (2008). 117-128.

[5] C.E. Cade, A.C. Dlouhy, K.F. Medzihradszky, S.P. Salas-Castillo, R.A. Ghiladi, Isoniazid-resistance conferring mutations in Mycobacterium tuberculosis KatG: Catalase, peroxidase, and INHNADH adduct formation activities. Protein Sci. 19 (2010) 458-474.

[6] R.D. Cramer, D.E. Patterson, J.D. Bunce, Comparative molecular field analysis (CoMFA). 1. Effect of shape on binding of steroids to carrier proteins. J Am Chem Soc. 110 (5) (1988) 59-67.

[7] P.D. Hawkins, A.G. Skillman, A. Nicholls, Comparison of shape-matching and docking as virtual screening tools. J Med Chem. 50 (2007) 74-82.

[8] M. Larif, S. Chtita, A. Adad, R. Hmamouchi, M. Bouachrine, T. Lakhlifi, Predicting biological activity of Anticancer Molecules 3-ary 1-4-hydroxyquinolin-2(1H)-one by DFT-QSAR models. Int J Adv Res Com. 6(3) (2013) 32-42

[9] Z. Li, H. Wan, Y. Shi, P. Ouyang, Personal experience with four kinds of chemical structure drawing software: review on ChemDraw, ChemWindow, ISIS/Draw, and ChemSketch. J Chem Inf Comput Sci. 44 (2004) 1886-90.

[10] C. Lee, W. Yang, R.G. Parr, Development of the Colle-Salvetti correlation-energy formula into a functional of the electron density. Phys Rev 37(2) (1988) 785-797.

[11] A.D. Becke, Becke's three parameter hybrid method using the LYP correlation functional. J Chem Phys. 98 (2) (1993) 5648-52. 